\title{
Analysis of the Impact of Human Capital Investment and Allocation on the Upgrade of Industrial Structure in Guangdong
}

\author{
En Chen, Mengmeng Zheng \\ College of Economics, Jinan University, Guangzhou, China \\ Email: mengmeng_273@163.com
}

How to cite this paper: Chen, E. and Zheng, M.M. (2017) Analysis of the Impact of Human Capital Investment and Allocation on the Upgrade of Industrial Structure in Guangdong. Open Journal of Business and Management, 5, 169-181.

http://dx.doi.org/10.4236/ojbm.2017.51016

Received: December 22, 2016

Accepted: January 14, 2017

Published: January 17, 2017

Copyright $\odot 2017$ by authors and Scientific Research Publishing Inc. This work is licensed under the Creative Commons Attribution International License (CC BY 4.0).

http://creativecommons.org/licenses/by/4.0/

c) (i) Open Access

\begin{abstract}
Industrial structure upgrade is a dynamic process of reallocating the factors of production. Human capital, as the most active factor of production, plays an important role in accelerating the upgrade of industrial structure. Taking Guangdong province as an example, this paper uses VAR model and structural deviation degree to examine the impact of human capital investment and allocation on the upgrade of industrial structure respectively. The VAR model result shows that the investment in human capital is the Granger cause of the upgrade of industrial structure, and the impulse response analysis proves that the improvement of human capital level has a long-term positive effect on the upgrade of industrial structure. According to the structural deviation degree, the current industrial distribution of human capital in Guangdong is very inefficient with a total deviation degree of $30 \%$, leading to a talent shortage in the secondary and tertiary industry. Besides, the unbalanced spatial distribution of human capital has widened the disparity of industrial structure among different regions in Guangdong. Finally, this paper puts forward some policy recommendations to solve these problems.
\end{abstract}

\section{Keywords}

Human Capital Investment, Human Capital Allocation, Industrial Structure Upgrade, VAR Model, Structural Deviation Degree

\section{Introduction}

In 2015, China's GDP growth slowed to 6.9\%, hitting its lowest level since 1990. After 30 years rapid development, China is currently in its crucial stage of economic restructuring. The latest 11th and 12th five-year plans both emphasize the urgency and significance of economic restructuring and made industrial structure upgrade as the top priority. In essence, industrial structure upgrade is a dynamic process of transferring 
the factors of production including natural sources, technology, physical capital and human capital from low-efficient industries to high-efficient industries. In the era of the knowledge economy, human capital, as the most active factor of production, plays an important role in accelerating the factor movement between industries. The stock and structure of human capital are decisive to the speed and efficiency of industrial structure upgrade.

Located in the south of China, Guangdong always takes the lead in the nation's economic reform. In 1979, Guangdong was nominated the pilot province to adopt reform and opening-up policy, which made it the major destination of early FDI and international industrial transfer. During the past 30 years, Guangdong's manufacturing industry has developed rapidly and established its status as the factory of the world. Affected by the financial crisis of 2008, Guangdong's manufacturing industry received unprecedented challenges, exposing the vulnerabilities of its former industrial structure. After the crisis, the government of Guangdong launched the famous Double Transfer Strategy, industry transfer and labor transfer respectively, to promote the transformation of industrial structure. In general, Guangdong is the epitome of China economy and the pioneer of industrial structure upgrade, which makes it the ideal sample for our study.

The structure of the paper is as follows. In Section 2 we briefly review and summarize the researches on human capital and industrial structure upgrade. Section 3 shows the evolution process of industrial structure over the period 1978-2014 in Guangdong. Sections 4 and 5 cover the empirical analyses. Section 4 uses the VAR model to examine the impact of human capital investment on the upgrade of industrial structure and reveals its mechanism. Section 5 employs the structural deviation degree to illustrate the impact of human capital allocation on industrial restructuring. Finally, Section 6 gives the conclusions and political recommendations.

\section{Related Literatures}

The relationship between human capital and economic growth has been discussed very intensively since 1960s. American economist Schultz (1960), father of modern human capital theory, put forward the concept of human capital when explaining the phenomenon of Mystery of Modem Economic Growth. In his definition, human capital referred to the knowledge, skill and working ability of an individual, and contributed more to the economic growth than physical capital [1]. Based on Schultz's study, Denison (1962) revised the econometric model and found that human capital investment accounted for 23\% of American economic growth over the period 1929-1957 [2]. In 1980s, Romer (1986) and Lucas (1988) included human capital in the growth equation as an independent variable and revealed that human capital is the main source of economic growth [3] [4]. Following Romer and Lucas, there has been an upsurge of empirical studies of human capital and economic growth (notably Barro (1991); Temple (1999) ) [5] [6]. Generally, foreign scholars have carried out a thorough study of the relationship between human capital and economic growth. However there are few researches about human capital and industrial structure upgrade.

With the introduction of modern human capital theory, Chinese scholars applied it into the research of industrial structure upgrade innovatively, and their findings can be 
divided into the following three aspects: i) the relationship between human capital and industrial structure upgrade. Zhao (2009) used the push and pull theory to illustrate the interactive relationship between human capital and industrial structure upgrade, and he believed that the current industrial structure was a dynamic equilibrium of the two forces [7]. Dai and Yang (2009) conducted a Granger causality test on the data of Jiangxi province, and found that human capital accumulation was the Granger cause of industrial structure upgrade but not vice versa [8]. Huang (2011) came to the similar conclusion at national level that there was only a one-way relationship between human capital and industrial structure upgrade [9]; ii) the impact of human capital investment on the upgrade of industrial structure. Liu and Zhang (2004) defined the human capital as a third form of capital in addition to existing physical capital and social capital, and regarded it as the engine of evolution of industrial structure in underdeveloped regions [10]. Ran and Mao (2009) summarized the production effect, knowledge effect and external effect of human capital, and pointed out that the effective supply of human capital would accelerate the adjustment of industrial structure [11]. Zhang (2011) set up an empirical model based on provincial panel data from 1978 to 2008 and found evidence for positive effects [12]; iii) the allocation of human capital and its impact on the upgrade of industrial structure. Zhang (2004) emphasized that the structure of human capital was a crucial factor to industrial restructuring. The irrational distribution of human capital would greatly weaken the final impact of human capital accumulation, thus affect the efficiency of industrial structure upgrade [13]. Jin (2011) further pointed out that the mismatch between human capital structure and industrial structure is the major cause of structural unemployment in China [14].

In summary, Chinese scholars have established a preliminary research framework of human capital and industrial structure upgrade. Inevitably, the previous studies have their own limitations. First, there are few in-depth researches into the mechanism of interaction. Second, most empirical works have only considered the impact of human capital investment, neglecting the impact of human capital allocation. In this paper, we will take Guangdong province as an example, using VAR model and structural deviation degree to examine the impact of human capital investment and allocation on the upgrade of industrial structure respectively, and give a further analysis on its mechanism.

\section{Evolution of Industrial Structure in Guangdong}

Figure 1 traces the evolution of industrial structure of Guangdong over the period 1978-2014. Consistent with classification of the National Bureau of Statistics, we divide the national economy into three industries. At the beginning of reform and opening-up policy, Guangdong undertook a large number of international industries transfer from Taiwan, Hong Kong, Macau and other areas, most of which were labor-intensive industries. Due to the industrial transfer, the added value of secondary industry increased rapidly and accounted for $46.6 \%$ of GDP in 1978. According to Figure 1, the initial ratio of added value of three industries was 29.8:46.6:23.6, with the tertiary industry being the lowest part. In the next few decades, the added value of tertiary industry rose steadily and exceeded the primary industry in 1985, then the secondary industry in 2011. 


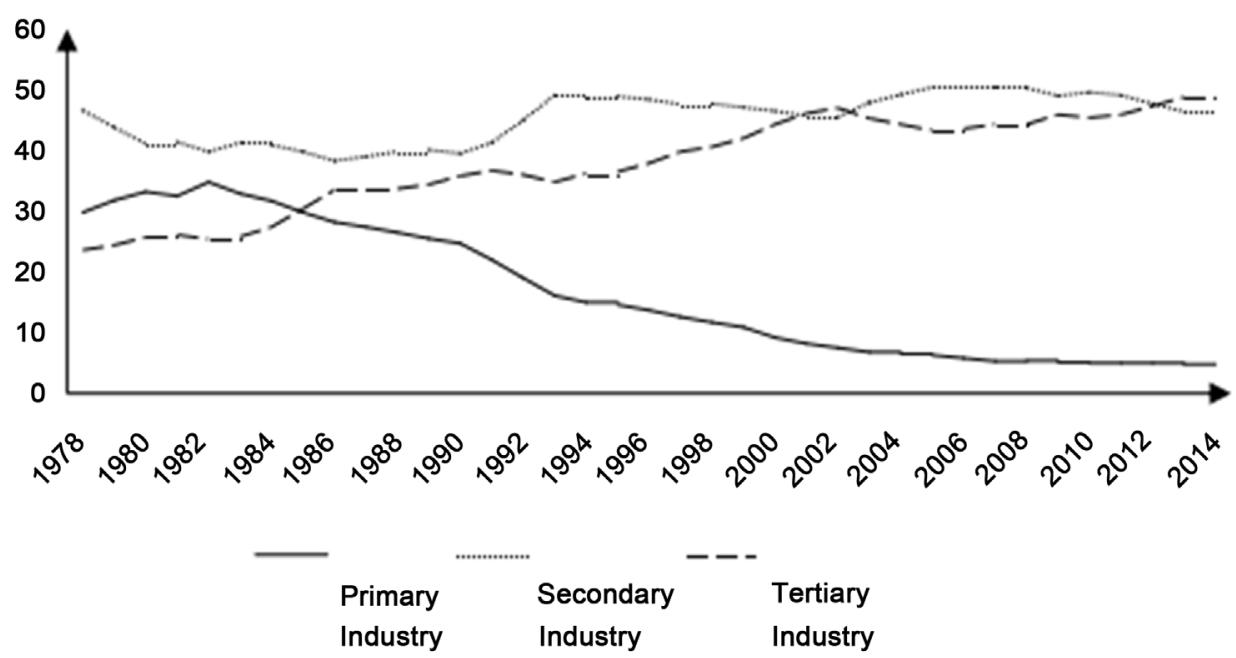

Figure 1. Composition of gross domestic product by industry in Guangdong (\%).

The unstable 3-2-1 industrial structure only lasted for two years as the secondary industry overtook the tertiary industry in 2003. Affected by the subprime mortgage crisis of 2008, the OEM industries, which used to be the main part of the secondary industry, received the hardest hit, leading to a dramatic decline in the proportion. Realizing the vulnerability of former industrial structure, the government of Guangdong province formulated Double Transfer Strategy, labor transfer and industrial transfer respectively. The industrial transfer strategy puts emphasis on transferring the labor-intensive industries out of the relatively more developed Pearl River Delta region and make room for high value-added industries, especially the modern service industry. Meanwhile the labor transfer strategy encourages the outflow of labor force from the primary industry to the secondary and tertiary industries. Since the promulgation of new strategy, the tertiary industry grew rapidly and built its leading position in 2013. The latest ratio of added value of three industries was 4.7:46.3:49 in 2014. Generally, the evolution of industrial structure in Guangdong is consistent with the general rules in Kuznets's work.

\section{The Impact of Human Capital Investment on the Upgrade of Industrial Structure}

\subsection{Testing Methodology and Data}

To capture the inter-dependencies and dynamic relationship between human capital investment and industrial structure upgrade, we choose the VAR model as our empirical method. A $p$-th order VAR can be specified as:

$$
y_{t}=c+A_{1} y_{t-1}+A_{2} y_{t-2}+\cdots+A_{p} y_{t-p}+\mu_{t}
$$

where $y_{t}$ is a $k \times 1$ vector of endogenous variables, $\mathrm{c}$ is a $k \times 1$ vector of constants, $A_{i}$ is a time-invariant $k \times k$ matrix, $y_{t-1}$ is the first order lag of $y_{t}, \mu_{t}$ is a $k \times 1$ vector of error terms which satisfy the hypothesis of white noise.

Consistent with the popular definition of industrial structure, we use the proportion of the primary industry in gross domestic product as the variable and define it as $\mathrm{S}$. The smaller the $S$ is, the more advanced the industrial structure will be. Human capital level, 
represented by $\mathrm{H}$, can be improved in multiple ways including education, on-the-job training, health investment and immigration, which makes it hard to measure its level. A common practice is to use education as a proxy variable for the reason that the better-educated individuals are more likely to obtain other kinds of human capital [15]. In this paper, we use the average years of schooling of employed persons to measure the initial level of human capital of Guangdong.

The data of the added value of three industries are taken from Guangdong Statistical Yearbook. The education data of employed persons from 1996 to 2013 come from China Labor Statistical Yearbook, with the data of 1982 and 1990 obtained from The Population Census of Guangdong Province, and the data of 1987 and 1995 from The 1\% Sample Survey of Population in Guangdong. Owing to the limitation of data, our sample interval ranges from 1982 to 2013, the omitted data will be filled by interpolation method.

\subsection{Empirical Results}

\subsubsection{Unit Root Test}

Our VAR model contains two variables of time series, namely $S$ and $H$. To avoid the potential problem of spurious regressions, we perform unit root tests to each series first. Specifically, we employ the Augmented Dickey Fuller tests to check for the stationarity of each series with the lags selected by Akaike's Information Criterion (AIC). Following the literature, all variables are transformed in logarithms before the tests. The results, listed in Table 1, show that the t-values of $\ln S$ and $\ln H$ are less than the critical value at $1 \%$ significance levels, which means both level series are stationary.

\subsubsection{Model Stability}

The optimal lag length selected by LR test statistic, AIC and SC criterion is equal to 4, and the estimation of VAR model is listed as follows:

$$
\begin{aligned}
{\left[\begin{array}{l}
\ln s_{t} \\
\ln h_{t}
\end{array}\right]=} & {\left[\begin{array}{l}
1.617367 \\
0.866207
\end{array}\right]+\left[\begin{array}{cc}
1.403239 & -0.265942 \\
-0.042905 & 0.309098
\end{array}\right]\left[\begin{array}{l}
\ln s_{t-1} \\
\ln h_{t-1}
\end{array}\right] } \\
& +\left[\begin{array}{ll}
-0.691476 & -0.552291 \\
-0.052969 & 0.359217
\end{array}\right]\left[\begin{array}{l}
\ln s_{t-2} \\
\ln h_{t-2}
\end{array}\right]+\left[\begin{array}{ll}
0.380707 & -0.590892 \\
0.304882 & 0.222207
\end{array}\right]\left[\begin{array}{l}
\ln s_{t-3} \\
\ln h_{t-3}
\end{array}\right] \\
& +\left[\begin{array}{ll}
-0.216818 & 0.780003 \\
-0.264375 & -0.220312
\end{array}\right]\left[\begin{array}{l}
\ln s_{t-4} \\
\ln h_{t-4}
\end{array}\right]+\left[\begin{array}{l}
\varepsilon_{1 t} \\
\varepsilon_{2 t}
\end{array}\right]
\end{aligned}
$$

The stability of VAR model can be tested by AR roots. As is shown in Figure 2, all the inverse roots of AR characteristic polynomial lie inside the unit circle, indicating that our VAR (4) model is stable.

Table 1. ADF tests for unit root.

\begin{tabular}{ccccc}
\hline Variable & $(\mathrm{C}, \mathrm{T}, \mathrm{K})$ & t-statistic & Critical value at $\%$ & Result \\
\hline $\ln S$ & $(\mathrm{~N}, \mathrm{~N}, 1)$ & $-2.680987^{*}$ & -2.644302 & stationary \\
$\ln H$ & $(\mathrm{C}, \mathrm{T}, 0)$ & $-4.345018^{*}$ & -4.284580 & stationary \\
\hline
\end{tabular}

${ }^{*}$ indicates that the null hypothesis is rejected at $1 \%$ level. $\mathrm{C}, \mathrm{T}, \mathrm{K}$ refers to intercept, trend, lag, respectively. 


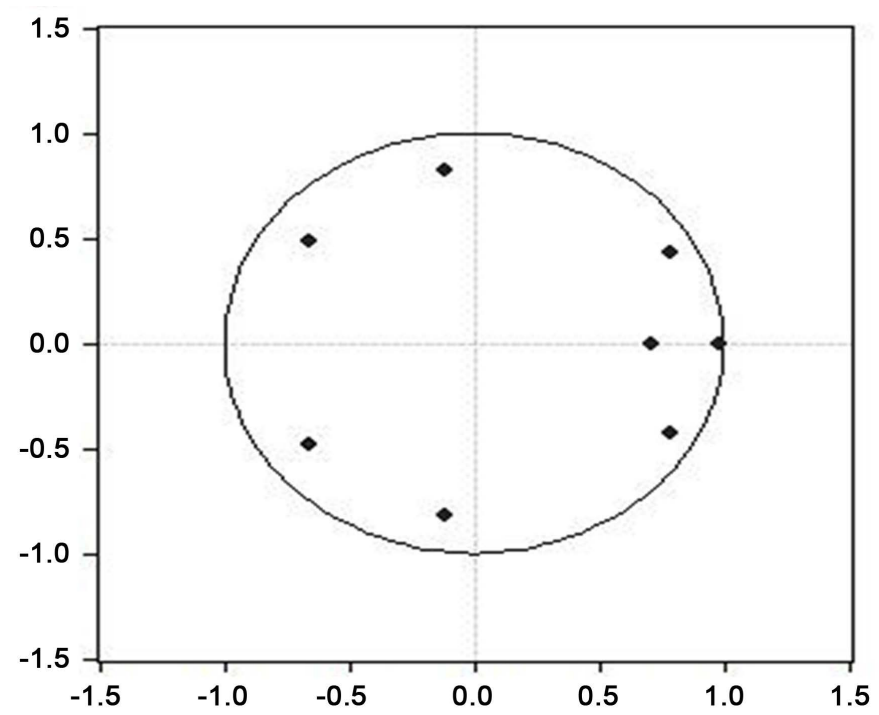

Figure 2. Inverse roots of AR characteristic polynomial.

\subsubsection{Granger Causality Tests}

Then, we perform Granger causality tests to examine the likely relationship between human capital investment and industrial structure upgrade. Given two time series, $Y_{t}$ and $X_{t}$. If time series $Y_{t}$ can be predicted better by using both past values of $Y_{t}$ and $X_{t}$ than using its own past value, then we say $X_{t}$ Granger causes $Y_{t}$. In other words, Granger causality tests only provide the "predictive causality". As is presented in Table 2, the null hypothesis that $\ln H$ dose not Granger Cause $\ln H$ is rejected at the $5 \%$ level of significance, while the other hypothesis is rejected at the $10 \%$ level of significance. The results indicate that the past level of human capital helps to forecast the future industrial structure of Guangdong. Besides, our results show the existence of a bi-directional causality relationship between human capital investment and industrial structure upgrade, which is different from Dai and Yang (2009) and Huang (2011) [8] [9].

\subsubsection{Impulse Response}

The aim of this section is to examine the impact of human capital investment on the upgrade of industrial structure. To conserve space, we only report the impulse response of $\ln S$ to $\ln H$. Figure 3 shows how a shock to human capital level will affect the contemporaneous and future industrial structure of Guangdong. Specifically, we consider one unit shock to $\ln H$. As is shown in Figure 3, $\ln S$ does not response in the first year, which means the impact of human capital investment on industrial structure upgrade is not instantaneous, with a time lag of approximate one year. In the second year, $\ln S$ begins to fall and shows a steady downward trend. The value of $\ln S$ reaches its lowest point of -0.048 in the seventh year and rises slightly in the next three year. During the period of our analysis, the value of $\ln S$ remains negative and the accumulative response values of $\ln S$ is -0.30 , suggesting that the improvement of human capital level will significantly decrease the proportion of the primary industry in gross domestic product. In other words, human capital investment has a positive and lasting effect on the upgrade of industrial structure in Guangdong. 


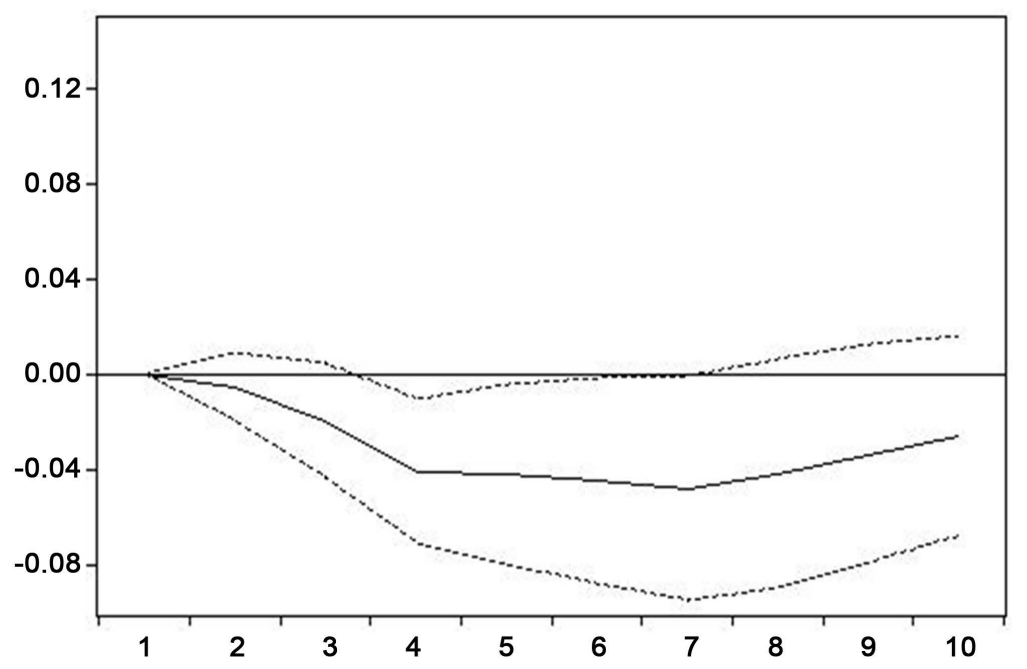

Figure 3. Impulse response of $\ln S$ to $\ln H$.

Table 2. Granger causality tests.

\begin{tabular}{cccc}
\hline Null hypothesis & df & P-value & Result \\
\hline $\ln H$ dose not Granger Cause $\ln S$ & 4 & 0.0233 & NO \\
$\ln S$ dose not Granger Cause $\ln H$ & 4 & 0.0657 & NO \\
\hline
\end{tabular}

\subsection{Mechanism Analysis}

The above empirical work has proved the existence of positive impact of human capital investment on the upgrade of industrial structure. This part tries to shed some light on the mechanism behind the influence. Two possible influence paths are provided in Figure 4 .

\subsubsection{The Technology Adoption Path}

Generally, the investment activities of human capital are quite unbalanced between different industries. A common phenomenon is that the tertiary industry invests far more than the primary and secondary industry. For example, industries such as the financial industry and scientific research industry are more likely to invest in human capital by recruiting employees with higher education levels and specialized expertise, establishing a complete on-the-job training system, providing gym facilities and additional medical care. It is a consensus that high level of human capital will facilitate the absorption of new technology. The industries with abundant human capital are easier to obtain the domestic and foreign frontier technology. Hence these human-capital-intensive industries should gains comparative advantages and experience rapid total factor productivity growth. As a result, the factors of production will flow to the human-capital-intensive industries automatically to acquire higher factor returns, and consequently accelerate the adjustment of industrial structure.

\subsubsection{The Consumer Demand Path}

The purpose of production is to satisfy consumer demand. In market economy, the basic question of what and how much to produce is determined by the aggregate preferences of all consumers. Thus, the evolution of consumer demand structure will di- 


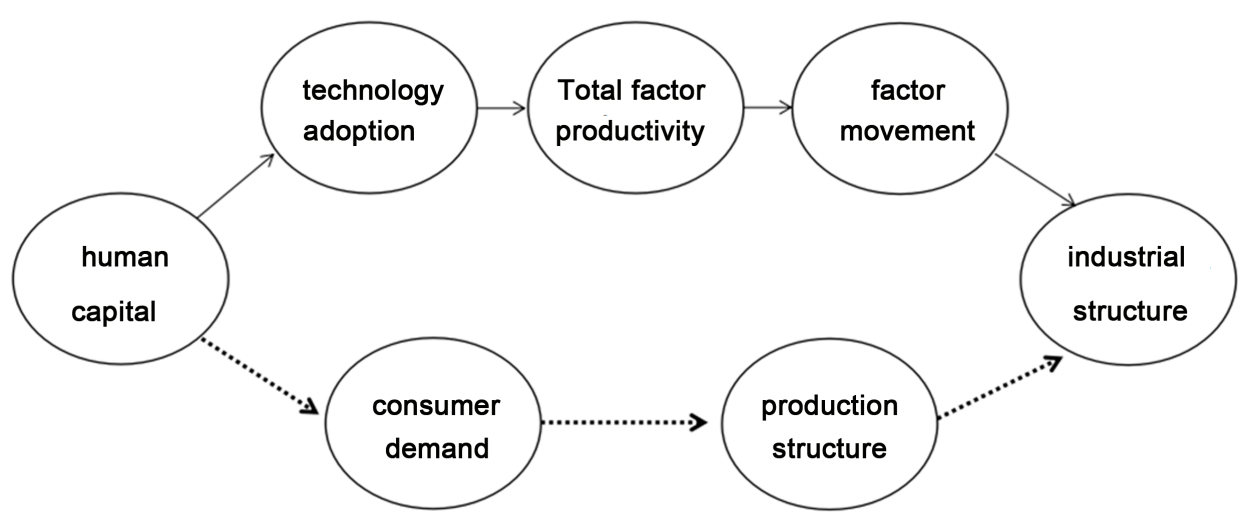

Figure 4. Two possible influence paths.

rectly affect the production structure, and subsequently the industrial structure. According to Mincer (1974), individual income level shows a positive correlation with human capital level [16]. As an individual improves his own human capital level, his wealth will grow as well. Given the different income elasticity of different demands, the hedonic demand including education, medical care, tourism and cultural needs will grow faster than the basic demand of clothes, food, housing and transportation, leading to an upgrade in consumer demand structure. To sum up, the improvement of human capital level, followed by a growth in income level, changes the production structure by affecting the consumer demand structure, ultimately resulting in the adjustment of industrial structure.

\section{The Impact of Human Capital Allocation on the Upgrade of Industrial Structure}

The former discussion has illustrated how human capital accumulation affects the transformation of industrial structure. This section will focus on the impact of human capital allocation. Basically, the allocation of human capital can be discussed from two aspects: the industrial level and the spatial level. With the adjustment of industrial structure, human capital, the most active factor of production, should flow between industries and regions to accommodate the demand of restructuring. The transfer speed of human capital will have a considerable impact on the efficiency of restructuring.

\subsection{The Industrial Distribution of Human Capital}

According to the definition of Hou (2001), the ideal industrial distribution of human capital should be equal to that of GDP [17]. Here we introduce "structural deviation degree" to measure the allocation efficiency of human capital. Given the proportion of the added value of industry $i$ as $x_{i}$ and the proportion of human capital of industry $i$ as $y_{i}$, the structural deviation degree $z_{i}$ equals to $x_{i}$ minus $y_{i}$, and the total deviation degree $Z$ is the sum of absolute values of $z_{i}$. The smaller $Z$ is, the more efficient the allocation of human capital will be.

$$
\begin{gathered}
z_{i}=x_{i}-y_{i} \\
Z=\sum z_{i}
\end{gathered}
$$


The stock of human capital is the product of average human capital level and the number of employed persons. For comparison, we will first analyze the structural deviation degree of the employed persons. As is shown in Table 3, there is a significant mismatch between employed persons and the added value of industries over the period 1990-2010, with the structural deviation degree of the primary industry above zero, while the values of the secondary and tertiary industries are both negative. The results indicate that the primary industry has a large number of surplus labor force, meanwhile the secondary and tertiary industries are suffering from severe labor shortage problems, which hinders the upgrade of industrial structure in Guangdong. We then estimate the stock of surplus labor force of the primary industry with the method provided by Rural Development Institute, and find that there are 12.45 million surplus employees in 2010, accounting for $81.33 \%$ of the total labor force of the primary industry. The household register system of China is the main cause of the mismatch, which restricts the outflow of rural labor force by administrative means. Another explanation of the mismatch can be found in Table 4 . The mobility of an employee is considered to be positively correlated with his own human capital level. In 2010, employees in the primary industry only receive an average of 8 years of education, equivalent to the primary school level. Besides, nearly $90 \%$ of workers of the primary industry do not have high school diploma, which restricts their access to the modern industrial sector and service sector in the terms of qualifications, resulting in a surplus of labor force in the agricultural sector.

The total deviation degree of human capital stays above 30\% over the period 1990-2010. In 2010, the deviation degrees of three industries are $-16.94 \%, 10.57 \%$ and $6.44 \%$, respectively. Overall, the signs of the deviation degree of human capital are

Table 3. The structural deviation degree of human capital and employed persons (\%).

\begin{tabular}{ccccccc}
\hline & \multicolumn{3}{c}{ Human capital } & \multicolumn{3}{c}{ Employed persons } \\
\cline { 2 - 6 } Year & $\begin{array}{c}\text { The } 1^{\text {st }} \\
\text { industry }\end{array}$ & $\begin{array}{c}\text { The } 2^{\text {nd }} \\
\text { industry }\end{array}$ & $\begin{array}{c}\text { The } 3^{\text {rd }} \\
\text { industry }\end{array}$ & $\begin{array}{c}\text { The } 1^{\text {st }} \\
\text { industry }\end{array}$ & $\begin{array}{c}\text { The } 2^{\text {nd }} \\
\text { industry }\end{array}$ & $\begin{array}{c}\text { The } 3^{\text {rd }} \\
\text { industry }\end{array}$ \\
\hline 1990 & -21.49 & 8.87 & 10.34 & -28.30 & 12.29 & 16.01 \\
1995 & -20.48 & 12.75 & 6.00 & -26.93 & 15.12 & 11.81 \\
2000 & -23.90 & 17.11 & 6.40 & -30.77 & 18.60 & 12.17 \\
2005 & -20.01 & 11.31 & 8.54 & -25.72 & 12.20 & 13.52 \\
2010 & -16.94 & 10.57 & 6.44 & -21.66 & 10.61 & 11.04 \\
\hline
\end{tabular}

All the data are re-calculated from The Population Census of Guangdong Province and The 1\% Sample Survey of Population in Guangdong.

Table 4. The education level of employed persons, 2010.

\begin{tabular}{ccccccc}
\hline Industry & $\begin{array}{c}\mathrm{H} \\
\text { (year) }\end{array}$ & $\begin{array}{c}\text { Semi-illiterate } \\
\text { or illiterate (\%) }\end{array}$ & $\begin{array}{c}\text { Primary } \\
\text { school (\%) }\end{array}$ & $\begin{array}{c}\text { Middle } \\
\text { school (\%) }\end{array}$ & $\begin{array}{c}\text { High } \\
\text { School (\%) }\end{array}$ & $\begin{array}{c}\text { College or } \\
\text { above (\%) }\end{array}$ \\
\hline The $1^{\text {st }}$ industry & 8.0 & 2.65 & 33.84 & 55.82 & 7.21 & 0.47 \\
The $2^{\text {nd }}$ industry & 9.8 & 0.26 & 10.77 & 60.55 & 21.14 & 7.28 \\
The $3^{\text {rd }}$ industry & 11.1 & 0.32 & 8.42 & 40.86 & 27.02 & 23.39 \\
\hline
\end{tabular}

$\mathrm{H}$ denotes the average schooling years. All the data are re-calculated from The Population Census of Guangdong Province (2010). 
consistent with that of employed persons, while the absolute value of the former is less than the latter. The main cause of this difference is that the average schooling years of the secondary and tertiary industries is longer than that of the primary industry, leading to a decrease in the value of $y_{1}$ and increase in $y_{2}$ and $y_{3}$, hence the decrease in the absolute value of $z_{i}$. This difference reminds us that in addition to the transfer of surplus labor force from the primary industry, it is also an effective way to decrease the mismatch by speed up the gathering of high level talents in secondary and tertiary industries. Moreover, both deviation degrees of human capital and employed persons drop sharply between 2005 and 2010, which can be mainly attributed to the implement of the Double Transfer Strategy in 2008, highlighting the fundamental role of government in realizing the optimal allocation of human capital.

\subsection{The Spatial Distribution of Human Capital}

According to the official classification, Guangdong province can be divided into four economic regions, the Pearl River Delta region, the eastern region, the western region and the mountainous region, respectively. Table 5 shows the gross domestic product and industrial structure of four regions in 2014, where the Pearl River Delta region maintains a leading position with the gross domestic product of 5.765 trillion Yuan, accounting for $78.8 \%$ of the total product of Guangdong, larger than three times the sum of the other three regions. In the terms of industrial structure, the Pearl River Delta region has formed the advanced 3-2-1 industrial structure with the added value ratio of 1.9:45:53.1, while the other three regions remain underdeveloped in the secondary and tertiary industries. According to the theories of industrialization, the Pearl River Delta region is now in the late stage of industrialization, while the eastern, western and mountainous regions of Guangdong have just entered the middle stage of industrialization. The spatial disparity of industrial structure is now the main obstacle to the development of Guangdong.

In addition to the traditional influence factors such as location, political status, infrastructure and FDI, the inter-regional movement of human capital might be underlying cause of the disparity. In the early years of reform and opening up, the Pearl River Delta region undertook the majority of labor-intensive industries transfer and created large amounts of job opportunities, leading to a wave of labor transfer. Over the period 1982-1990, the resident population the Pearl River Delta region had increased by 5.78 million, equivalent to receiving an average of 0.72 million migrants from the other regions and provinces each year. The agglomeration of population formed a huge supply

Table 5. The industrial structure by region, 2014 (billion Yuan).

\begin{tabular}{ccccc}
\hline Region & GDP & The $1^{\text {st }}$ industry & The $2^{\text {nd }}$ industry & The $3^{\text {rd }}$ industry \\
\hline Guangdong & $73,120.77$ & 3193.49 & $33,102.46$ & $36,824.85$ \\
PRD & $57,650.02$ & 1068.60 & 25941.28 & $30,640.14$ \\
Eastern & 5064.17 & 419.63 & 2800.94 & 1843.60 \\
Western & 5776.57 & 986.54 & 2430.17 & 2359.86 \\
\hline
\end{tabular}

PRD refers to the Pearl River Delta region. All the data are taken from Guangdong Statistical Yearbook (2015). 
pool of skilled labors, cutting down the costs of factories to search for qualified workers. Besides, the spatial proximity increased their opportunities of technical exchange and access to the frontier technologies. As a result, more factories were moved to there and offered new job opportunities in return. To sum up, the agglomeration of industries in the Pearl River Delta region promoted the accumulation of human capital and vice versa. As for the eastern, western and the mountainous region of Guangdong, these regions lost the first-mover advantage of industrial transfer in the beginning. In the pursuit of high wages and job prospects, millions of young labor force left these regions and flew to the Pearl River Delta region. As a result of brain drain, the secondary and tertiary industries developed at a relatively slow pace, which in turn exacerbated the outflow of labor force and stepped into a vicious circle.

Table 6 presents the imbalance distribution of human capital of Guangdong in 2010. Statistics show that the Pearl River Delta region, less than a third of Guangdong's land area, has a labor pool of 35.72 million workers in 2010, accounting for $60.8 \%$ of the total, far more than the sum of the other three regions. Besides, the employees in the Pearl River Delta region receive an average of 10.2 years of education, the highest in Guangdong, and $13.65 \%$ of who have got college degree or above, the proportion in other regions is less than 7\%. Overall, the Pearl River Delta region maintains its dominance whether in quantity or in quality of labor force. The shortage of human capital has become the main obstacle to the rise of the eastern, western and mountainous regions of Guangdong.

\section{Conclusions}

Our results can be summarized as follows: i) human capital investment is the Granger cause of industrial structure upgrade, and there exists a bi-directional causality relationship between them; ii) the impact of human capital investment on industrial structure upgrade is not instantaneous with a time lag of approximate one year. In the long run, the improvement of human capital level has a positive and lasting effect on the upgrade of industrial structure in Guangdong; iii) there are two mechanisms through which human capital could affect the adjustment of industrial structure: facilitating the adoption of technology and changing the consumer demand; iv) the industrial distribution of human capital in Guangdong is quite inefficient with a total deviation degree of $30 \%$. The primary industry has a large number of surplus labor force, meanwhile the

Table 6. The stock of human capital by region, 2010.

\begin{tabular}{cccccccc}
\hline Region & $\begin{array}{c}\mathrm{H} \\
\text { (year) }\end{array}$ & $\begin{array}{c}\text { Employees } \\
\text { (billion) }\end{array}$ & $\begin{array}{c}\text { Semi-illiterate } \\
\text { or illiterate (\%) }\end{array}$ & $\begin{array}{c}\text { Primary } \\
\text { school (\%) }\end{array}$ & $\begin{array}{c}\text { Middle } \\
\text { school (\%) }\end{array}$ & $\begin{array}{c}\text { High } \\
\text { school (\%) }\end{array}$ & $\begin{array}{c}\text { College or } \\
\text { above (\%) }\end{array}$ \\
\hline Guangdong & 9.7 & 58.705 & 0.87 & 15.69 & 53.12 & 19.59 & 10.73 \\
PRD & 10.2 & 35.72 & 0.35 & 10.78 & 52.42 & 22.79 & 13.65 \\
Eastern & 8.8 & 7.658 & 1.29 & 25.87 & 53.79 & 14.53 & 4.52 \\
Western & 8.9 & 7.243 & 2.57 & 24.39 & 52.99 & 13.83 & 6.23 \\
Mountainous & 9.1 & 8.084 & 1.39 & 21.63 & 56.05 & 14.20 & 6.73 \\
\hline
\end{tabular}

$\mathrm{H}$ denotes the average schooling years. PRD refers to the Pearl River Delta region. All the data are re-calculated from The Population Census of Guangdong Province (2010). 
secondary and tertiary industries are suffering from severe labor shortage problems, which hinder the upgrade of industrial structure; v) the inter-regional movement of human capital is the main cause of regional disparity of industrial structure in Guangdong. With the outflow of young labor force, the eastern, western and mountainous regions of Guangdong are suffering from severe labor shortage and step into a vicious circle.

According to the above analyses, we give the following policy recommendations: i) increase the education budget. The average education level of employees, even in the Pearl River Delta region, is relatively low compared with the developed countries. The former nine-year compulsory education policy has achieved great success, and the next step is to increase the education budget to raise enrollment rates of high school or above; ii) remove the obstacles to the transfer of rural labor force. It is urgent to reform the existing household register system and broaden employment channels for surplus labor force. The government of inflow regions must take action to provide equal job opportunities and citizenship treatment for the migrant workers. The government of outflow regions should establish special institutes to offer employment information and training services to accelerate the transfer of surplus labor force; iii) promote the agglomeration of human capital in the eastern, western, and mountainous regions of Guangdong. The key to breaking the vicious circle in these underdeveloped regions is to promote the accumulation of human capital. To attract and retain talents, government could make some preferential policies such as raising salaries, offering public rental housing, medical care and children's education service.

\section{References}

[1] Schultz, T.W. (1961) Investment in Human Capital. American Economic Review, 1, 1-17.

[2] Denison, E.F. (1962) The Sources of Economic Growth in the United States and the Alternatives before Us. Committee for Economic Development, New York.

[3] Romer, P.M. (1986) Increasing Returns and Long-Run Growth. Journal of Political Econo$m y$, 5, 1002-1037. https://doi.org/10.1086/261420

[4] Lucas, R.E. (1988) On the Mechanics of Economic Development. Journal of Monetary Economics, 1, 3-42. https://doi.org/10.1016/0304-3932(88)90168-7

[5] Barro, R.J. (1991) Economic Growth in a Cross Section of Countries. The Quarterly Journal of Economics, 2, 407-443. https://doi.org/10.2307/2937943

[6] Temple, J. (1999) The New Growth Evidence. Journal of Economic Literature, 1, 112-156. https://doi.org/10.1257/jel.37.1.112

[7] Zhao, G.H. (2008) Research on the Interactive Relationship between Human Capital and Industrial Structure. Commercial Research, 2, 34-39.

[8] Dai, Q.W. and Yang, J.R. (2007) The Empirical Analysis of the Relationship between Human Capital and Industrial Restructuring: Evidence from Jiangxi Province. Jiangxi Social Sciences, 12, 123-126.

[9] Huang, W.Z. (2011) Identifying Human Capital Impacts on Industrial Structure Upgrade in VAR Models. Inquiry into Economic Issues, 3, 24-27.

[10] Liu, G.Z. and Zhang, S. (2004) The Impact of Human Capital on the Transformation of Industrial Structure: Evidence from Northeast China. Inquiry into Economic Issues, 6, 9095.

[11] Ran, M.S. and Mao, Z.B. (2008) The Mechanism Analysis of Human Capital to Economic 
Growth. Journal of Chongqing University, 1, 56-59.

[12] Zhang, G.Q., Wen, J. and Tang, X.J. (2011) Human Capital and Its Structure and Industry Structure Upgrading. China Population Resources \& Environment, 10, 138-146.

[13] Zhang, L.J. (2004) Analysis on the Development of Human Capital and Industrial Structure in Western China. Gansu Social Sciences, 3, 170-174.

[14] Jin, W.D. (2010) The Effect of Dynamic Machine between Human Capital and Industrial Structure Transformation. Economic Review, 6, 137-142.

[15] Yao, X.G. and Zhang, H.F. (2008) Education, Human Capital and Regional Economic Differentials. Economic Research Journal, 5, 47-57.

[16] Mincer, J. (1974) Schooling Experience and Income. Columbia University Press, New York.

[17] Hou, Y.F. and Wang, J.Y. (2001) Human Capital and Transition in Mode of Economic Growth. Population Research, 3, 13-19.

\section{Submit or recommend next manuscript to SCIRP and we will provide best service for you:}

Accepting pre-submission inquiries through Email, Facebook, LinkedIn, Twitter, etc. A wide selection of journals (inclusive of 9 subjects, more than 200 journals)

Providing 24-hour high-quality service

User-friendly online submission system

Fair and swift peer-review system

Efficient typesetting and proofreading procedure

Display of the result of downloads and visits, as well as the number of cited articles

Maximum dissemination of your research work

Submit your manuscript at: http://papersubmission.scirp.org/

Or contact ojbm@scirp.org 